\title{
Factors Causing Intraocular Lens Damage During Implantation in Phacoemulsification Surgery
}

\author{
Fakoemülsifikasyon Cerrahisinde Implantasyon Sırasında Gelişen Göz Içi Lens Hasarına \\ Neden Olan Faktörler
}

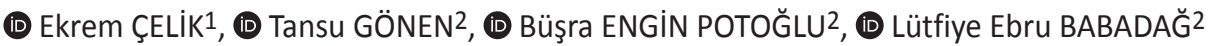 \\ ${ }_{1}^{1}$ Tekirdağ Dr. İsmail Fehmi Cumalıoğlu City Hospital, Clinic of Ophthalmology, Tekirdağ, Turkey \\ ${ }^{2}$ Tekirdağ Namık Kemal University Faculty of Medicine, Health Practice and Research Hospital, Clinic of Ophthalmology, Tekirdağ, Turkey
}

\begin{abstract}
Aim: To evaluate the factors affecting intraocular lens (IOL) integrity during implantation in phacoemulsification surgery.

Materials and Methods: In this study, medical records of 3,856 patients (4,778 eyes) who underwent phacoemulsification and foldable IOL implantation by cartridge between August 2010 and July 2019 were retrospectively reviewed. The 11 eyes of 11 patients who had undergone IOL removal and reimplantation were noted for IOL damage during implantation. In other eyes, implanted IOL material, injector and cartridge type information were recorded.

Results: The properties of implanted 4,195 IOLs of 4,778 were hydrophobic acrylic (835 SA60AT, 2,438 AAB00, 922 ZCB00). The remaining 583 IOLs were hydrophobic surfaced high water content acrylic (UD 613). Hydrophobic acrylic IOLs with high water content were inserted with a disposable plastic syringe and foldable cartridge, and hydrophobic acrylic IOLs were inserted with a reusable metal syringe and disposable non-foldable cartridge. Of the 11 IOLs whose integrity was impaired during implantation, 8 were hydrophobic surfaced high water content acrylic and 3 were hydrophobic acrylic $(p<0.001)$. There was no statistically significant difference between hydrophobic acrylic lenses $(p=0.103)$.

Conclusion: The material structure of the one-piece hydrophobic surfaced high water content acrylic foldable IOLs, the implantation system and foldable cartridge used are the factors that can potentiate the development of damage in the IOL during implantation. For a problem-free implantation, it should be done carefully and slowly from inserting the IOL into the cartridge until it is placed in the capsule bag.
\end{abstract}

Keywords: Phacoemulsification, intraocular lens damage, intraocular lens exchange

ÖZ

Amaç: Fakoemülsifikasyon cerrahisinde implantasyon sırasında göz içi lens (GiL) bütünlüğünü etkileyen faktörleri değerlendirmek.

Gereç ve Yöntem: Bu çalışmada, Ağustos 2010-Temmuz 2019 tarihleri arasında fakoemülsifikasyon ve kartuş yardımlı katlanabilir GiL implantasyonu yapılmış 3.856 hastanın (4.778 göz) tıbbi kayıtları geriye dönük olarak incelendi. İmplantasyon sırasında GilL bütünlüğü bozulan 11 hastanın 11 gözü çalışmaya dahil edildi. Diğer gözlerin Gíl ve implantasyon sistemi verileri kaydedildi.

Bulgular: İncelenen 4.778 GíL'nin 4.195'i hidrofobik akrilik (835'i SA60AT, 2.438'i AAB00 ve 922'si ZCB00) ve 583'ü hidrofobik yüzeyli yüksek su içerikli akrilik (UD 613) idi. Hidrofobik yüksek su içerikli akrilik Gil'ler tek kullanımlık plastik enjektör ve katlanan kartuş, hidrofobik akrilik Gil'ler yeniden kullanılabilir metal enjektör ve tek kullanımlık katlanmayan kartuş ile göz içine yerleştirilmişti. Bütünlüğü bozulmuş 11 GiL'in 8'i hidrofobik yüzeyli yüksek su içerikli akrilik iken 3'ü hidrofobik akrilikti $(p<0,001)$. Hidrofobik akrilik Gil'ler kendi aralarında kıyaslandığında istatistiksel olarak anlamlı fark görülmedi $(p=0,103)$.

Sonuç: Tek parça hidrofobik yüzeyli yüksek su içerikli akrilik katlanabilir GiL'lerin materyal yapısı, kullanılan implantasyon sistemi ve katlanabilir kartuş yapısı, implantasyon sırasında GíL'de hasar gelişimine neden olabilecek faktörlerdir. Sorunsuz bir implantasyon için, GiL'nin kartuşa yerleştirilmesinden kapsül içine yerleştirilene kadar geçen süreçte dikkatli ve yavaş uygulama yapılmalıdır.

Anahtar Kelimeler: Fakoemülsifikasyon, göz içi lens hasarı, göz içi lens değişimi

Address for Correspondence: Ekrem ÇELiK MD, Tekirdağ Dr. İsmail Fehmi Cumalığlu City Hospital, Clinic of Ophthalmology, Tekirdağ, Turkey Phone: +90 5055169835 E-mail: ekcelik@gmail.com ORCID ID: orcid.org/0000-0002-1455-4931

Received: 06.12.2020 Accepted: 07.03.2021

๑Copyright 2021 by the Tekirdağ Namık Kemal University Faculty of Medicine / Namık Kemal Medical Journal published by Galenos Publishing House. 


\section{INTRODUCTION}

Intraocular lens (IOL) implantation during the modern phacoemulsification procedure is one of the basic principles of successful cataract surgery. With the introduction of foldable IOLs in modern surgeries, $10 \mathrm{~L}$ implantation has become possible through a smaller corneal incision. In the historical development process of cataract surgery, many IOL and IOL implantation systems have been developed to increase the success of surgeries. While the IOL is placed in the eye with various injector systems and cartridges, complications requiring IOL replacement may occur. Some of these complications include damage to the lens capsule and zonule or damage to the IOL optic and haptic structure of the IOL during implantation. As a result of not being able to centralize the optic of the $10 \mathrm{~L}$, a decrease in visual acuity may occur after surgery. If the IOL optic cannot be centralized as a result of damage to the optic or haptic structure of the IOL, explantation and re-implantation should be performed ${ }^{1,2}$.

In this study, we aimed to evaluate the effects of two different injector and cartridge systems used during intraocular implantation of one-piece hydrophobic and hydrophobic surfaced with high water content acrylic, two types of acrylic IOLs with different material properties, on possible IOL damage.

\section{MATERIALS AND METHODS}

4778 eyes of 3856 patients who underwent phacoemulsification and cartridge-assisted one-piece foldable IOL implantation between August 2010 and July 2019 in Tekirdağ Namık Kemal University Department of Ophthalmology and did not develop complications other than IOL damage during and after the procedure were analyzed retrospectively. The technical characteristics and IOL implantation systems of the IOLs used in all surgeries, the corneal incision length of the eyes containing the IOLs damaged during implantation, the location of the IOL damage, the IOL strength and the implantation order within their group were recorded. This study was approved by Tekirdağ Namık Kemal University Ethics Committee (numbered 2019.09.11.06) and complies with the 2008 Helsinki Declaration. All patients were informed about all stages of the surgical procedure and informed consent was obtained from the patients.

Phacoemulsification and IOL implantation were performed under topical, regional (subtenon and retrobulbar) or general anesthesia. For pupil dilation, phenylephrine $2.5 \%$, cyclopentolate $1 \%$ and tropicamide $0.5 \%$ drops were applied 3 times with intervals of 5 minutes, 30 minutes before surgery. Topical anesthesia was provided with proparacaine hydrochloride $0.5 \%$ drops 4 times at 5 minuteintervals, 20 minutes before the procedure. Regional anesthesia was provided with a mixture of $2 \mathrm{~mL} 2 \%$ lidocaine hydrochloride and $2 \mathrm{~mL} \mathrm{0.5 \%} \mathrm{bupivacaine} \mathrm{hydrochloride.} \mathrm{Povidone} \mathrm{iodine} \mathrm{was}$ used for surgical area cleaning. For endophthalmitis prophylaxis, $5 \%$ povidone iodine was dropped to the fornix; After 3 minutes, it was washed with Ringer's lactate solution. Two clear corneal side incisions were made with a 20 gauge $(G)$ micro vitreoretinal knife. A cohesive viscoelastic agent ( $1.4 \%$ sodium hyaluronate) was injected into the anterior chamber. The main corneal incision was made with a slit blade (in various incisions between $2.2 \mathrm{~mm}$ and $3.2 \mathrm{~mm}$ ). A flap was created in the anterior capsule with a $27 \mathrm{G}$ cystotome. Continuous curvilinear capsulorhexis was performed with capsulorhexis forceps. After hydrodissection and hydrodelineation, the nucleus was aspirated by shredding with stop and chop and quick chop methods. Lens cortex and residuals were cleaned by bimanual irrigation and aspiration method. All procedures were carried out by experienced three surgeons. Two separate nurses experienced in phacoemulsification procedures inserted the IOL into the cartridge. The cartridge was first wetted with a balanced salt solution, then filled with a cohesive viscoelastic material, and the IOL was made ready for implantation. Hydrophobic acrylic IOLs SA60AT (AcrysoF, Alcon, Fortworth, TX, US), AAB00 (Sensar 1, Abbott Medical Optics, Santa Ana, CA, US) and ZCB00 (Tecnis 1, Abbott Medical Optics, Santa Ana, CA, US) were implanted by disposable non-folded cartridge and reusable metal syringe (Figure 1A); hydrophobic surfaced high water content acrylic IOL UD 613 (Acriva, VSY Biotechnology, İstanbul, Turkey) was implanted by folded disposable cartridges and disposable plastic syringe (Figure 1B) ${ }^{3,4}$. After filling the capsule with cohesive viscoelastic, the IOL was placed in the capsule. In order to remove the IOLs that were seen to be damaged during implantation and whose centralization could not be achieved, the IOL incision was made with micro scissors to the center of the $\mathrm{IOL}$ optic without expanding the corneal incision. The IOL was rotationally removed from the main corneal incision by holding one side of the incised IOL with colibri forceps. Another IOL of the same feature and diopter was implanted in the capsule. Drops containing topical steroid (prednisolone acetate $1 \%$ ) and antibiotic (moxifloxacin 0.5\%) were started in all patients after surgery. The drops were stopped by gradually reducing the

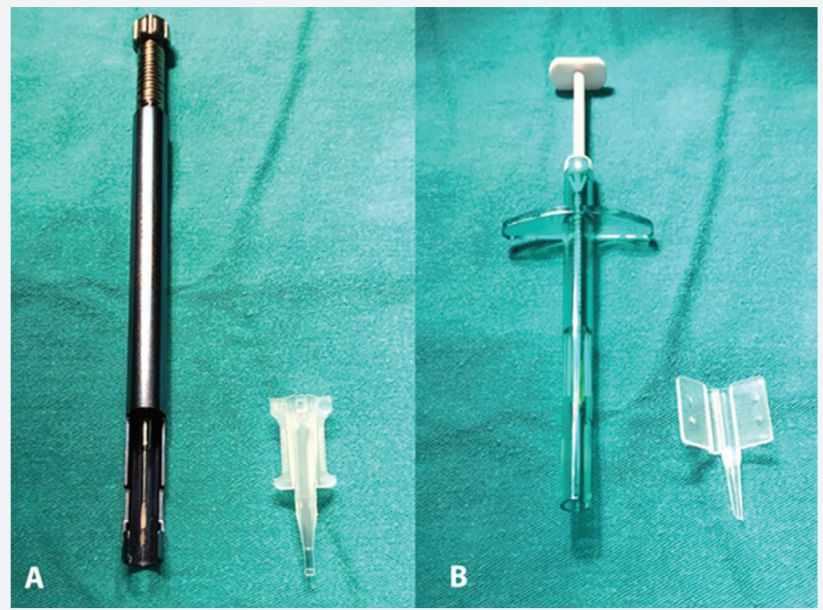

Figure 1. A) Reusable metal injector and disposable nonfolded cartridge; B) disposable plastic injector and disposable folding cartridge 
number of doses within two weeks. The IOLs used were divided into 2 groups as hydrophobic acrylic and hydrophobic surfaced high water content acrylic.

\section{Statistical Analysis}

The statistical analyses were performed using Statistical Package for the Social Sciences Statistics for Windows, version 24.0 (IBM, Statistical Product and Service Solutions, Inc., Chicago, IL, USA). The difference between groups was evaluated using the chisquare and Fisher's exact tests. $\mathrm{P}<0.05$ was considered statistically significant.

\section{RESULTS}

Of the 4,778 IOLs implanted in the eye after phacoemulsification, 4,195 were hydrophobic one-piece acrylic (835 SA60AT, 922 ZCB00 and 2,438 $A A B 00$ ) and 583 were hydrophobic surfaced high water content one-piece acrylic UD613 (Acriva) (Table 1). IOL integrity was impaired in 11 patients who were implanted (Table 2). Of the 11 IOLs whose integrity was impaired by damage, 8 were hydrophobic surfaced high water content and 3 were hydrophobic acrylic

\begin{tabular}{|c|c|c|c|c|c|}
\hline $\begin{array}{l}\text { IOL, } \\
\text { group }\end{array}$ & $\begin{array}{l}\text { IOL, } \\
\text { model }\end{array}$ & $\begin{array}{l}\mathrm{IOL}, \\
\text { implanted, } \\
\text { n }\end{array}$ & $\begin{array}{l}\mathrm{IOL}, \\
\text { damaged, } \\
\text { n }\end{array}$ & $\begin{array}{l}\text { IOL, } \\
\text { total, } \\
\text { n }\end{array}$ & $\begin{array}{l}p \\
\text { value }\end{array}$ \\
\hline \multirow{3}{*}{$\begin{array}{l}\text { Hydrophobic } \\
\text { acrylic }\end{array}$} & SA60AT & 835 & 2 & \multirow{3}{*}{4195} & \multirow[b]{4}{*}{$<0.001$} \\
\hline & ZCB00 & 922 & 0 & & \\
\hline & AAB00 & 2438 & 1 & & \\
\hline $\begin{array}{l}\text { Hydrophobic } \\
\text { surfaced } \\
\text { high water } \\
\text { content } \\
\text { acrylic }\end{array}$ & UD613 & 583 & 8 & 583 & \\
\hline \multicolumn{6}{|c|}{ IOL: Intraocular lens } \\
\hline
\end{tabular}

$(p<0.001)$. When the hydrophobic acrylic IOLs with 3 different designs from two different manufacturers with 8 damaged lenses were compared, the difference was not statistically significant $(p=0.103)$. No complications occurred during the explantation and re-implantation of the IOLs. Of the 8 IOLs with a hydrophobic surfaced high water content acrylic, 7 of them had haptic damage and 1 had optic damage. Haptic damage was observed in 3 of the hydrophobic acrylic IOLs. Two of the hydrophobic surfaced high water content acrylic IOLs had low diopter and were thin. The other 2 IOLs in the same group were damaged during the learning period of the cartridge insertion procedure. The main corneal incision length varied between 2.2 and $3.2 \mathrm{~mm}$ (Table 2).

\section{DISCUSSION}

The characteristics of the material which the IOL is produced, its optical and haptic design, the implantation system used, improper placement of the IOL in the cartridge, inappropriate placement of the cartridge in the implantation system, inappropriate and inadequate viscoelastic use, and inappropriate cartridges are factors that can adversely affect the IOL integrity during phacoemulsification procedures ${ }^{5,6}$.

Foldable acrylic IOLs are the most commonly used materials in phacoemulsification and IOL implantation currently. Although there are one-piece, 3-piece, plate haptic or scleral fixation IOLs in use, we used only one-piece IOLs with haptics in our study. Acrylic IOLs can also be classified as hydrophilic acrylic, hydrophobic surfaced high water content acrylic or hydrophobic acrylic. Hydrophobic IOLs have a water content of less than 1\%, while those with hydrophilic and hydrophobic surfaces contain water between $18 \%$ and $26 \% 0^{5,7}$.

Hydrophilic IOLs consist of a hydroxyethyl methacrylate (polyHEMA) and hydrophilic acrylic monomer. They are soft and their hydrophilic nature provides excellent flexibility. It is possible

Table 2. Properties of damaged intraocular lens

\begin{tabular}{|c|c|c|c|c|c|c|c|}
\hline IOL & IOL, model & $\begin{array}{l}\mathrm{IOL}, \\
\text { design }\end{array}$ & $\begin{array}{l}\mathrm{IOL}, \\
\text { implantation } \\
\text { system }\end{array}$ & $\begin{array}{l}\text { IOL, } \\
\text { Damage } \\
\text { localization }\end{array}$ & $\begin{array}{l}\text { Corneal } \\
\text { incision width } \\
\text { (millimeter) }\end{array}$ & $\begin{array}{l}\text { IOL, power } \\
\text { (diopter) }\end{array}$ & $\begin{array}{l}\mathrm{IOL} \text {, } \\
\text { implantation } \\
\text { order }\end{array}$ \\
\hline 1 & UD613 & $\mathrm{MC}$ & $\mathrm{T}$ & Haptic & 2.8 & 20.50 & $22 / 583$ \\
\hline 2 & UD613 & $M C$ & $T$ & Haptic & 2.8 & 21.00 & $38 / 583$ \\
\hline 3 & UD613 & $M C$ & $T$ & Haptic & 3.2 & 28.00 & $96 / 583$ \\
\hline 4 & UD613 & MC & $\mathrm{T}$ & Optic & 3.2 & 24.00 & $244 / 583$ \\
\hline 5 & UD613 & $\mathrm{MC}$ & $T$ & Haptic & 2.8 & 19.00 & $547 / 583$ \\
\hline 6 & UD613 & $\mathrm{MC}$ & $\mathrm{T}$ & Haptic & 2.8 & 18.00 & $575 / 583$ \\
\hline 7 & UD613 & $\mathrm{MC}$ & $\mathrm{T}$ & Haptic & 2.4 & -1.00 & $579 / 583$ \\
\hline 8 & UD613 & $\mathrm{MC}$ & $\mathrm{T}$ & Haptic & 2.4 & 0.00 & $580 / 583$ \\
\hline 9 & AAB00 & C & $Y$ & Haptic & 2.4 & 21.50 & $1199 / 2438$ \\
\hline 10 & SA60AT & C & $Y$ & Haptic & 2.4 & 22.00 & $681 / 835$ \\
\hline 11 & SA60AT & C & $Y$ & Haptic & 2.2 & 21.50 & $782 / 835$ \\
\hline
\end{tabular}


to be implanted through corneal incisions below two millimeters. It is resistant to damage caused by folding. Because of the high rate of posterior capsule concentration development in hydrophilic IOL implantations, the use of hydrophobic surface and hydrophilic hybrid IOLs has become widespread. These are mostly coated with hydrophobic acrylic on the surface and contain ultrapure acrylate monomer that has a water content of $25 \% 0^{5,8,9}$.

Hydrophobic IOLs consist of a series of acrylate and methacrylate copolymers. Rigid polymethylmethacrylate has been transformed into a foldable and durable material. Pull and push force can be applied to hydrophobic IOLs; IOLs can take their old shape in seconds. It can be inserted into the eye through a corneal incision of at least $2.2 \mathrm{~mm}^{5,7,8}$.

SA60AT, which is a hydrophobic acrylic IOL, has an aspherical and biconvex front surface, while its back surface has a $360^{\circ}$ sharp optical edge. Its haptics are "C" shaped and a continuation of optics $^{10}$. ZCB00 and AAB00 are other hydrophobic acrylic IOLs; Biconvex, front surface aspherical and posterior surface has an optical square edge $360^{\circ 11}$. The implantation of these IOLs is done with reusable metal injectors and disposable non-folding cartridges designed for these injectors. The IOL is placed in the cartridge groove and the plunger of the metal injector is pushed forward and inserted into the eye. The metal plunger is smaller than the cartridge groove and its rigid structure allows it to push the IOL without compressing the haptics and optics. The resistant nature of the hydrophobic material to pulling, pushing and compression reduces the possibility of IOL damage ${ }^{12}$.

UD613 is a hydrophilic acrylic IOL with a high water content (25\%) with a hydrophobic surface and consists of one-piece optics and haptics. It is aspherical and has a modified " $\mathrm{C}$ " shaped haptics and is applied into the eye with a disposable plastic implantation system and a suitable disposable foldable cartridge ${ }^{13}$. In this system, the $\mathrm{IOL}$ is placed in the cartridge, then the cartridge flaps are closed and the IOL is folded. While the cartridge flaps are closed, the haptics or optical cartridge can remain between the flaps or the haptics may get stuck between the soft injector plunger and the cartridge while the IOL is injected into the eye. The high water content soft biomaterial structure of hydrophilic acrylic IOLs is also considered as another reason that increases the possibility of damage to the optic and haptics during folding and implantation ${ }^{4,14}$. In this study, optic damage was observed in 1 of the disintegrated lenses, while haptic damage developed in all of the others. According to our observations, the compression of the haptic between the plunger and the lumen of the cartridge caused damage during the closure of the cartridge after the IOL was placed in the cartridge or while it was pushed forward by the plunger in the cartridge lumen. If the IOL pushed by the plunger in the cartridge lumen is too thin or thick, that is, it has a very high or low power, it may cause difficulties in pushing the IOL forward. Thick IOLs can get stuck at the exit of the cartridge lumen; thin ones can remain between the piston and the lumen ${ }^{4}$. The very thin optical and haptic structures of the very low power $(0.00$ and -1.00 D) 2 IOLs in Table 2 may be the cause of their damage.

IOLs of different manufacturers are implanted into the eye with different cartridge and implantation systems designed for them. IOLs to be used for the first time may be damaged while being placed in the cartridge and eye during the learning process $5,6,14$. In our study, 2 of the hydrophobic surfaced high water content acrylic IOLs were damaged during the learning process. In the other group IOLs, the hydrophobic acrylic was not damaged during this process. Our observations suggest that features related to the cartridge and implantation system used, as well as experience, may also cause IOL damage.

Indication for IOL explantations are IOL damage, malposition, miscalculation of power and performance failure, opacification or staining. While damage rarely develops in one-piece acrylic IOLS, breakage can be seen mostly in the optic-haptic junction of threepiece IOLs ${ }^{4,6,15}$. Mamalis et al. ${ }^{14}$ evaluated explantations and reimplantations, which they compiled from studies published until 2003, in terms of almost all types of IOLs currently in widespread use until that day. They also compared the damage-related change rate in one-piece hydrophobic acrylic IOLs with haptics changes due to other complications and found $7.5 \%$. Other complications that cause IOL change are opacification, discoloration, incorrect lens power, dislocation, retinal surgery, decentration and glare. In one-piece hydrophilic acrylic IOLs with haptics, it was found that the change was mostly due to discoloration/opacification (70\%). In the survey update study conducted by the same colleagues in 2007, no damaged lenses were reported in one-piece hydrophobic acrylic IOLs. They found that there was no notification of damaged lenses in one-piece hydrophilic acrylic IOLs, and the ratio of discoloration/opacification rate to other explantations this time was $60 \%$. It was reported in the 2007 survey that the use rate of one-piece haptic hydrophobic acrylic IOLs increased compared to other material and design lenses, but no damaged lenses were seen. The effect of reducing the damage is the elimination of the imperfectness in implantation systems and cartridge technology, and the increase in the one-piece hydrophobic acrylic with haptics IOL using experience ${ }^{14,15}$.

There are studies reporting that the choice of viscoelastic device used while placing the IOL in the cartridge causes IOL damage ${ }^{6}$. Insufficient viscoelastic substance into the cartridge or keeping the $\mathrm{IOL}$ in the cartridge for a long time may cause the IOL to stick to the cartridge ${ }^{16}$. Injecting a viscoelastic device with less pseudoplasticity into the cartridge may cause IOL damage ${ }^{17}$. In order to prevent the IOL from jamming during implantation, it is necessary to ensure sufficient wetting with a balanced salt solution and to ensure that the IOL is completely covered with viscoelastic. A slow and careful implantation while inserting into the cartridge and pushing with the injector plunger will help maintain IOL integrity ${ }^{18}$. 
Various techniques have been described for the removal of the damaged $I \mathrm{LL}^{19-23}$. The removal of the $\mathrm{IOL}$ can be performed by widening the main corneal incision or by dividing the IOL into many parts without expanding the incision site. After the viscoelastic device is injected into the anterior chamber and under the IOL, the IOL is divided into many parts with these techniques ${ }^{2}$. In addition, the IOL can be made suitable for removal by cutting haptics and optics using ND-YAG laserer. In the partial transection technique, the lens is cut in full thickness up to the center of the IOL optic, and it is held at one end with forceps and removed by rotation without expanding the corneal incision ${ }^{21,25}$. In our study, damaged IOLs were removed using the partial transection technique.

\section{Study Limitations}

The limitations of our study were the small number of cases, retrospective examination and the difference in the number of IOLs used between the groups. The fact that more than one surgeon perform the procedures has revealed the risk of low standardization between applications. The absence of such case series in the literature made it difficult to compare the study with other possibilities. We think that a study in which we will implant the same IOL type into the eye using different implantation systems will better reveal the factor that causes damage.

\section{CONCLUSION}

Today, there are many IOLs and their implantation systems made by different manufacturers with different materials and designs. The structural features of the hydrophobic surfaced high water content IOLs' cartridge and implantation system, which may have difficulties in the learning process, may cause damage to the IOL during implantation. For a problem-free implantation, we should be slow and careful during the period from inserting the IOL into the cartridge to pushing it forward into the capsule using the plunger.

\section{Ethics}

Ethics Committee Approval: This study was approved by Tekirdağ Namık Kemal University Ethics Committee (numbered 2019.09.11.06) and complies with the 2008 Helsinki Declaration.

Informed Consent: All patients were informed about all stages of the surgical procedure and informed consent was obtained from the patients.

Peer-review: Externally peer-reviewed.

\section{Authorship Contributions}

Surgical and Medical Practices: E.Ç., T.G., B.E.P., L.E.B., Concept: E.Ç., T.G., Design: E.Ç., T.G., L.E.B., Data Collection or Processing: E.Ç., T.G., B.E.P., L.E.B., Analysis or Interpretation: E.Ç., T.G., B.E.P., L.E.B., Literature Search: E.Ç., T.G., B.E.P., Writing: E.Ç., T.G., B.E.P., L.E.B.
Conflict of Interest: No conflict of interest was declared by the authors.

Financial Disclosure: The authors declared that this study received no financial support.

\section{References}

1. Lee GA, Dal Pra ML. Cracked acrylic intraocular lens requiring explantation. Aust N Z J Ophthalmol. 1997;25:71-3.

2. Singh SK, Winter I. Explantation of damaged foldable acrylic lens with implantation of foldable intraocular lens without enlarging incision. Kathmandu Univ Med J (KUMJ). 2008;6:239-41.

3. Olson R, Cameron R, Hovis $T$, Hunkeler J, Lindstrom R, Steinert R. Clinical evaluation of the Unfolder. J Cataract Refract Surg. 1997;23:1384-9.

4. Harsum S, Mann S, Clatworthy I, Lewin J, Little B. An investigation of intraocular lens damage and foreign bodies using an injectable hydrophilic acrylic lens implant. Eye (Lond). 2010;24:152-7.

5. Bellucci R. An introduction to intraocular lenses: material, optics, haptics, design and aberration. Cataract. ESASO Course Series. Basel, Karger 2013;3:38-55.

6. Singh $A D$, Fang $T$, Rath R. Cartridge cracks during foldable intraocular lens insertion. J Cataract Refract Surg. 1998;24:1220-2.

7. Tognetto D, Toto L, Sanguinetti G, Cecchini P, Vattovani O, Filacorda S, et al. Lens epithelial cell reaction after implantation of different intraocular lens materials: two-year results of a randomized prospective trial. Ophthalmology. 2003;110:1935-41.

8. Huang , Cheng GP, Chiu K, Wang GQ. Surface Modification of Intraocular Lenses. Chin Med J (Engl). 2016;129:206-14.

9. Özyol P, Özyol E, Karel F. Biocompatibility of Intraocular Lenses. Turk J Ophthalmol. 2017;47:221-5.

10. Davison JA. Clinical performance of Alcon SA30AL and SA60AT single-piece acrylic intraocular lenses. J Cataract Refract Surg. 2002;28:1112-23.

11. Wahba SS, Riad RF, Morkos FF, Hassouna AK, Roshdy MM. Visual performance of the Tecnis one-piece lens ZCB00. Clin Ophthalmol. 2011;5:1803-8.

12. Remón L, Siedlecki D, Cabeza-Gil I, Calvo B. Influence of material and haptic design on the mechanical stability of intraocular lenses by means of finiteelement modeling. J Biomed Opt. 2018;23:1-10.

13. Akkuş ÖG, Petriçli IS. Comparison of visual outcomes and reading performance after bilateral implantation of multifocal intraocular lenses with bilateral monofocal intraocular lenses. Int Ophthalmol. 2018;38:1011-9.

14. Mamalis N, Brubaker J, Davis D, Espandar L, Werner L. Complications of foldable intraocular lenses requiring explantation or secondary intervention--2007 survey update. J Cataract Refract Surg. 2008;34:1584-91.

15. Grabow HB. Indications and techniques of intraocular lens removal. 2005;2-9.

16. Olson RJ. Cartridge cracks with different viscoelastic agents. J Cataract Refract Surg. 1999;25:465-6.

17. Saxena $R$, Sinha $A$, Khokhar $S$, Dhawan $M$, Turuka K. Intraoperative cracking of the AMO Phacoflex-II Silicone (SI-40NB) intraocular lens while implanting with the Unfolder silver series system using hydroxypropylmethylcellulose. Indian J Ophthalmol. 2007;55:396-7.

18. Pfister DR. Stress fractures after folding an acrylic intraocular lens. Am J Ophthalmol. 1996;121:572-4.

19. Lee $\mathrm{MH}$, Webster $\mathrm{DL}$. Intraocular lens exchange-removing the optic intact. Int J Ophthalmol. 2016;9:925-8.

20. Osher RH. Crisscross lensotomy: New explantation technique. J Cataract Refract Surg. 2006;32:386-8.

21. Batlan SJ, Dodick JM. Explantation of a foldable silicone intraocular lens. Am J Ophthalmol. 1996;122:270-2.

22. Por YM, Chee SP. Trisection technique: a 2-snip approach to intraocular lens explantation. J Cataract Refract Surg. 2007;33:1151-4.

23. Zheng D, Zhang Z, Yang W, Chen W. Foldable lens explantation and exchange: the reason and solution. Yan Ke Xue Bao. 2001;17:54-6.

24. Marques FF, Marques DM, Smith CM, Osher RH. Intraocular lens exchange assisted by preoperative neodymium:YAG laser haptic fracture. J Cataract Refract Surg. 2004;30:247-9.

25. Mehta JS, Wilkins MR, Gartry DS. Explantation of an acrylic Acrysof intraocular lens without wound enlargement. Acta Ophthalmol Scand. 2005;83:262-3. 